\title{
Configuraciones de la lengua en La casa de los conejos de Laura Alcoba.
}

\section{Language's Configurations in La casa de los conejos by Laura Alcoba.}

\section{Resumen}

El presente artículo estudia una novela de la posdictadura argentina, escrita en francés, a saber, La casa de los conejos (2007) de Laura Alcoba. El eje central del trabajo está dado por la lengua y sus múltiples relaciones con la historia -la historia de la violencia de Estado- que narra la novela. En primer lugar, se analiza el hecho de que el texto está escrito en francés a pesar de que la lengua materna de la autora es el español: Alcoba debió exiliarse, a sus diez años, en Francia junto a su madre. En segundo lugar, se vislumbra que más allá de que el idioma de escritura sea el francés, hay palabras puntuales que -aún en el original- se escriben en español. Tales términos funcionan como metonimia de una lengua entera (el español), como símbolo de una historia (la del terrorismo de Estado) y como metonimia, a la vez, de la literatura de la posdictadura argentina: esas palabras representan el hecho de contar una historia de forma alternativa a los relatos oficiales de la época.

Palabras claves Laura Alcoba, Lengua, Posdictadura, Horror.

\begin{abstract}
This article studies a novel written in the argentinean posdictatorship, in French, La casa de los conejos (2007) by Laura Alcoba. The main concept of the paper is the mother and second tongue and its multiples links with the history -the history of state violence- that novel relates. First of all, it is studied the fact that text is written in French in spite of author's mother tongue is Spanish: Alcoba had to go into exile during the period of the "Triple A" in Argentina. In second place, it is observed that beyond this fact, there are several words written in Spanish. Such words work as metonymy of a whole language (Spanish), as a symbol of a history (the state terrorism) and at the same time, they work as a metonymy of posdictatorship argentinean literature: those words represent the capital fact to telling a history in another way of that one of the oficial history.
\end{abstract}


CATEDRAL TomadA: Revista de crítica literaria latinoamericana / Journal of Latin American Literary Criticism Configuraciones de la lengua en La casa de los conejos de Laura Alcoba.

Keywords Laura Alcoba, Language/Tongue, Posdictatorship, Horror.

\section{Historia y ficción}

Durante los últimos treinta años, aproximadamente, el cruce entre historia y ficción se presenta como una estrategia frecuente en la escritura literaria de Latinoamérica en general y de Argentina en particular. Se trata de la ficcionalización de acontecimientos y procesos históricos así como de discursos y actores sociales y las identidades que a ellos se vinculan.

Ante tal rasgo, se suscita un interrogante, a saber, a qué objetivos responde el que la literatura tome como materia ciertos hechos que comúnmente se situarían en el terreno del relato historiográfico. A partir de esto urge rastrear las especificidades de la escritura literaria en el tratamiento de tales temas, al tiempo que es menester entender tanto el posicionamiento y el punto de vista que adopta la práctica literaria frente aquellos, cuanto el sitio desde el cual erige su propio discurso. En esta dirección, el lugar de la literatura como portadora de un discurso valioso, diferente de los demás, ha sido frecuentemente sostenido por teóricos y escritores. Ernst Fisher plantea que "es menester mantenerse informado sobre la realidad", por lo que el lenguaje del periodista, por mencionar tan sólo uno, "no basta para posibilitar una visión clara de la realidad [...] para convencer a los hombres de que son capaces de transformar el curso del destino. Esta labor exige la intervención del artista, del poeta, del escritor" (63). Cercana a esta idea se halla la que postula Nicolás Rosa: "lo que define a la literatura es ese menos donde se afirma y se funda. Una falta histórica, sociológica, psicoanalítica (para mencionar los saberes dominantes) que la revela como lo faltante del discurso social, como lo no-dicho del discurso colectivizado" (11). Ya lo señalaron Brecht y los primeros teóricos del lenguaje con las ideas de extrañamiento y desautomatización: 
CATEDRAL TOMADA: Revista literaria latinoamericana / Journal of Latin American Literary Criticism Estefanía Luján Di Meglio

Bertolt Brecht y los formalistas rusos pensaron que el arte está en condiciones de iluminar lo que nos rodea de modo más inmediato a condición de que produzca un corte por extrañamiento, que desvíe a la percepción de su hábito y la desarraigue del suelo tradicional del sentido común. La puesta en cuestión de lo acostumbrado es la condición de un conocimiento de los objetos más próximos, a los que ignoramos precisamente porque permanecen ocultos por la familiaridad que los vela. Esto rige también para el pasado. (Sarlo, Tiempo 53)

La cita de Beatriz Sarlo conjuga esta noción de extrañamiento (la ostranenie de los formalistas rusos), el observar los hechos y fenómenos como si se lo hiciera por primera vez que operan las disciplinas artísticas en general, con las revisiones del pasado histórico como objeto de su producción.

Con la crisis de la representación y las cesuras del paradigma epistemológico, ya desde la década de los '80, todo relato y discurso se ven sujetos a revisión (Cf. Iggers). A esto viene a añadirse el denominado giro subjetivo (Sarlo, Tiempo; Arfuch). En el caso del discurso historiográfico en particular, la óptica totalizadora y objetiva se descubre como un imposible. Frente a ello y haciéndose eco de los nuevos postulados, la literatura forja su propia narrativa histórica, siempre sobre la base de sus especificidades. Tal como lo asevera María Coira, "en los últimos veinte años, aproximadamente, se ha producido una fuerte tendencia en la novelística hispanoamericana caracterizada por los cruces, intersecciones y préstamos mutuos entre historia y ficción” (23). Es que, como sostiene Fernando Ainsa, "en la libertad que da la creación se llenan vacíos y silencios o se pone en evidencia la falsedad de un discurso" (10). Por su parte, Roland Barthes reflexiona en torno a la idea de que el discurso histórico es esencialmente "elaboración ideológica, o para ser más precisos, imaginario. El historiador no puede obviar ni deformar deliberadamente los resultados de su investigación, pero opera en un espacio donde interactúan su específico saber y las ideologías, las exigencias de la escritura y sus propias creencias" (Fibla 22). 
En el marco de un cambio de paradigma que afecta las formas de acceso y apropiación del conocimiento, la construcción de los relatos y las prácticas discursivas (tomando el concepto de Foucault), emerge una narrativa, entonces, que se presenta como otro modo de escribir la historia y que constituye, con frecuencia, una expresión alternativa de ciertos discursos dominantes: lo invalidan, lo cuestionan, rellenan sus vacíos o luchan contra el olvido impuesto (Fibla 24).

En el caso argentino la literatura, desde la misma época del gobierno de facto, se ha ocupado de desmantelar el discurso elaborado e instaurado por los regímenes militares y sus antesalas políticas (Masiello, Sarlo, Sosnowski, entre otros, han tratado el tema) y lo ha hecho, podría decirse, en etapas, en el sentido de que la generación coetánea a los acontecimientos produce sus novelas y sus textos de no ficción (pueden citarse los casos ejemplares de Rodolfo Walsh, Ricardo Piglia o Tomás Eloy Martínez) e inaugura una serie puntual de reescritura de los sucesos. Ya hacia fines de los años noventa aparece una nueva narrativa cuyos protagonistas han vivido de modo muy marginal (por edad, porque no fueron partícipes directos, entre otros motivos) los episodios concretos. Los mecanismos de percepción de los hechos se encuentran, ahora, diseminados en las atmósferas, en el desplazamiento de las técnicas militares a escenarios disímiles que ponen sobre el tapete cierta anomalía aceptada y, al mismo tiempo, percibida como extraña pero indecible, y en la imposición de silencios en diferentes épocas -que van desde el eufemismo a la omisión. En la posdictadura, las lecturas y escrituras que se llevan a cabo articulan lo silenciado y ocultado por los discursos oficiales del período del régimen castrense con aquello que sí ha sido dicho y mostrado, pero que ahora se vislumbra bajo focos diferentes, con miradas, perspectivas y enfoques que construyen representaciones desplazadas de las oficiales así como de ciertas figuraciones alternativas, operando desplazamientos tanto en el plano del discurso como en el nivel de las historias narradas o, lo que es lo mismo, en los planos de la enunciación y el enunciado. Los cuestionamientos y relecturas se actualizan sobre tejidos discursivos forjados en el 
pasado pero también sobre representaciones y figuraciones de ellos en los tiempos posdictatoriales. La literatura de la última década del siglo XX y de la primera del XXI establece un distanciamiento con los hechos que le permite construir nuevas versiones de la historia, alejadas del relato oficial de aquel momento -al que, como las narrativas que la han precedido, desmantela y denuncia- pero también desplazada de esa literatura de no ficción o testimonial y de la narrativa de los años 80 en términos de los mecanismos discursivos que utiliza y que, en definitiva, la constituyen como particular. Como lo señala Martín Kohan, la literatura, por ser ella misma polisémica y plural, se configura como espacio propicio para la manifestación de las contradicciones y paradojas de la arena de lo social: "La literatura aparece y prospera justamente con la torsión, con la infracción, con la aventura, con la travesura [...]” (169). Todo esto tiene como causa y a la vez resultado la constante puesta en tela de juicio de representaciones discursivas y del propio relato, el cual se encuentra fragmentado, dislocado, desplazado de sus referentes y significaciones, apelando a la multiplicidad de sentidos siempre plurales y nunca cerrados. Asimismo, se trata de una crisis de la representación reduplicada y potenciada por el carácter traumático de la historia.

\section{Lenguaje y horror}

Que el lenguaje no es presentación de las cosas, sino mediación que representa aquello que nombra, se convirtió en premisa aceptada desde la antigüedad pero no fue siempre tenida en cuenta. Es recién a comienzos del siglo pasado cuando se retoma esta idea (Steiner, Extraterritorial 110)-con los trabajos pioneros de Ludwig Wittgenstein- y se instala hacia mediados de siglo como problemática teórica que atraviesa diversas disciplinas. "Ninguna lengua, por más amplio que sea su vocabulario o más original y refinada su gramática puede organizar la totalidad potencial de la experiencia" (Steiner, Extraterritorial 119). Si esto es así en términos generales, más profundidad aún adquiere en el caso de 
las historias signadas por el horror, en tanto que, al producirse en ellas una dificultad en la verbalización, la crisis de la representación se ve acentuada.

Cuenta Tzvetan Todorov (1970) que ya en el siglo V a.C. se genera la conciencia de que el relato y las cosas en sí mismas (los hechos, las historias, los objetos, las emociones) van por caminos diferentes. Los simbolistas, miles de años más tarde, dudarán de la correspondencia entre el lenguaje y los objetos, con lo que advertirán que no hay una relación de equivalencia entre ambos: la lengua es mediación. Por su parte, las vanguardias históricas -que abrevan de las fuentes de la poesía moderna- reconocen la no linealidad entre las palabras y las cosas que ellas designan: descubren una opacidad en el lenguaje. Vladimir Jankélévitch exhibe la paradoja que se encierra entre los polos posibilidad-imposibilidad de la expresión a través del lenguaje: "En un sentido, el lenguaje es un impedimento para expresarse, pero el hombre no puede expresarse sino porque está impedido de expresarse. El impedimento de expresarse es el medio de expresión, porque somos hombres" (18). De igual manera y desde la lingüística, Ivonne Bordelois advierte que "en verdad, el lenguaje no nos es suficiente, pero nos es necesario; la palabra sola no puede salvarnos, pero no nos podemos salvar sin la palabra" (136). Por su parte, Maurice Blanchot arguye respecto de la palabra escrita: "Mas repitamos con Levinas, a pesar de que privilegie el Decir como don de significancia: 'El lenguaje ya es escepticismo'. Escribir es desconfiar absolutamente, entregándosele absolutamente, de la escritura" (El paso 96). Resulta que dos guerras mundiales y el genocidio nazi brindarán la pauta de que el lenguaje se torna insuficiente para designar esas realidades que escapan a toda lógica corriente.

Ya lo advirtió Walter Benjamin (1991) pasada la Primera Guerra al ver retornar a los soldados enmudecidos, en parte debido a la dificultad de hablar y de articular un discurso sobre lo visto y vivido. Theodor Adorno (1962) lo manifestó en términos figurativos, al señalar que es cosa barbárica escribir poesía después de Auschwitz. En suma, los autores cuyo objeto se recorta de la narración de este tipo de experiencias coinciden en que "lo traumático es por definición 
irrepresentable" (Balardini, Oberlin, Sobredo 178). En un lugar intermedio, se halla la tensión ya señalada por Giorgio Agamben y que enfatiza Michael Pollak a propósito del testimonio: “[...] la tensión creada entre la necesidad y la dificultad de testimoniar" (da Silva Catela en Pollak 13). Esto no es otra cosa que lo que dimensiona Primo Levi bajo el concepto de "paradoja del testimonio" (la “aproximación dialéctica" en términos de Georges Didi-Huberman, Imágenes 158): es imposible dar cuenta del horror, esto es, testimoniar, pero a la vez se torna imprescindible hacerlo puesto que si no, se estaría concediendo la victoria a los perpetradores, quienes en los campos de concentración nazis aseveraban que nadie sobreviviría para contar lo vivido, que ellos (los genocidas) escribirían la historia, y que en el caso de que alguien la relatara, nadie les creería. De allí que el objetivo sea "dar cuenta de la imposibilidad de testimoniar" (la mencionada paradoja) (Agamben 8, 19, 34). En cuanto a las estrategias de representación en la esfera artística, Paula Fleisner sostiene algo semejante: “el campo mismo es lo que prohíbe la representación: es imposible mostrar lo que mata toda posibilidad de imagen, salvo que se rehaga el gesto del asesino. Sólo una representación que haga presente su (ir)representabilidad propia, podrá salir airosa de la sospecha de haberse entregado a los placeres de la representación" (72). Pero es que, además y como Levi advierte, el lenguaje mismo ha sido otra víctima del genocidio: "Entonces por primera vez nos damos cuenta de que nuestra lengua no tiene palabras para expresar esta ofensa, la destrucción de un hombre" (26), puesto que el habla de la vida cotidiana nada tiene que ver con la de los campos de concentración, en cuanto que se trata de dos lógicas totalmente diferentes:

Del mismo modo que nuestra hambre no es la sensación de quien ha perdido una comida, así nuestro modo de tener frío exigiría un nombre particular. Decimos "hambre", decimos "cansancio", "miedo" y "dolor", decimos "invierno", y son otras cosas. Son palabras libres, creadas y empleadas por hombres libres que vivían, gozando y sufriendo, en sus casas. Si el Lager hubiera durado más, un nuevo lenguaje áspero habría 
CATEDRAL TomadA: Revista de crítica literaria latinoamericana / Journal of Latin American Literary Criticism Configuraciones de la lengua en La casa de los conejos de Laura Alcoba.

nacido; y se siente la necesidad de él para explicar lo que es trabajar todo el día al viento, bajo cero, no llevando encima más que la camisa, los calzoncillos, la chaqueta y unos calzones de tela, y, en el cuerpo, debilidad y hambre y conciencia del fin que se acerca. (133-134)

Igual fenómeno es señalado por otro sobreviviente, Jorge Semprún:

No hay más que dejarse llevar. La realidad está ahí, disponible. La palabra también. No obstante, una duda me asalta sobre la posibilidad de contar. No porque la experiencia vivida sea indecible. Ha sido invivible, algo del todo diferente, como se comprende sin dificultad. Algo que no atañe a la forma de un relato posible, sino a su sustancia. No a su articulación, sino a su densidad. Sólo alcanzarán esta sustancia, esta densidad transparente, aquellos que sepan convertir su testimonio en un objeto artístico, en un espacio de creación. O de recreación. Únicamente el artificio de un relato dominado conseguirá transmitir parcialmente la verdad del testimonio. Cosa que no tiene nada de excepcional: sucede lo mismo con todas las grandes experiencias históricas. (25)

Por su parte, Bruno Bettelheim sostiene que "Nuestras viejas categorías no resisten la confrontación con los campos de exterminio", a lo que añade: "Pero si guardamos silencio, haremos exactamente lo que los nazis querían: comportarnos como si no hubiese pasado nada. Si guardamos silencio, permitimos que los falsificadores de la realidad presenten al mundo una interpretación engañosa de uno de los capítulos más trágicos de la historia moderna" (127). En efecto, la lógica que rige la experiencia traumática escapa a los marcos interpretativos disponibles en los sistemas de representación tradicionales, en cuanto que constituye una experiencia "excepcional" (Vezzetti 111). Es por ello que "el genocidio nazi puso en entredicho las categorías de la representación" (Crenzel 11; Fleisner 63), lo que puede hacerse extensible a las modernas dictaduras 
latinoamericanas. En resumen, la traducibilidad de lo traumático al lenguaje cotidiano se torna imposible si lo que se pretende es cifrar un relato acabado, puesto que el horror escapa a la lógica de la representación: lo traumático produce un vacío de significante (Insúa 24), un hiato en la aprensión del significado, perforando el lenguaje humano. No obstante, la articulación de un discurso que se acerque al horror, que bordee los límites del trauma es posible, en cuanto que, como lo aseveraban Agamben y Fleisner, las formas en las que (no) se puede hablar de lo ominoso son ya un modo de representarlo. ${ }^{1}$

\section{Lengua y exilio}

"La separación de una persona de la tierra donde vive", tal como lo define el diccionario de la Real Academia Española en su primera acepción, es, en su sentido literal y lineal, tan sólo el estado material y la cristalización más pragmática y tangible del exilio. Tantos otros aspectos y eventos están incluidos en él, por lo que la anterior definición resulta escasa frente lo que éste implica. El desarraigo intrínseco al abandono forzado de la propia tierra convoca otros desarraigos que trascienden el del espacio entendido en su talante geográfico complejo en sí mismo. Simplemente basta pensar en la amplitud de significados de la palabra tierra y se verá que gran parte de lo que aquél engendra es objeto de separación. Cuando la patria que recibe tiene otra lengua (aun cuando posee la misma lengua, la variedad lingüística difiere), el desarraigo se extiende al lenguaje.

1 Dominick LaCapra esboza reflexiones similares: "Las técnicas convencionales son particularmente inadecuadas en relación a acontecimientos que son realmente límites. Al ocuparnos de ellos, el lenguaje puede no ser útil y la forma más apropiada de representación puede resultar minimalista. [...] Por otra parte, aquí el silencio no equivale a un simple mutismo y el modo en que fracase el lenguaje es en sí un proceso significante e incluso revelador. En cualquier caso, el usuario del lenguaje -incluyendo al historiador- se halla bajo limitaciones y obligaciones especiales, a las que suele evitar apoyándose en procedimientos convencionales" (63). 
A los diez años de edad, Laura Alcoba emprendió el exilio. Escritora nacida en Cuba pero de padres argentinos y residente en Argentina durante su infancia, su desarraigo fue motivado por el de su madre; y causado éste por el prolegómeno político de la más sangrienta dictadura en Argentina. Militante política perseguida por la fuerza parapolicial de la Alianza Anticomunista Argentina (conocida también como la "Triple A"), que actuó durante el gobierno de María Estela de Perón, la madre no vio otra salida más que la de atravesar las fronteras del país. El de la escritora sería un exilio en "segundo grado", en tanto fue motivado por el de un familiar. Francia fue su destino.

Décadas más tarde, Alcoba encuentra en la escritura el lugar del exilio² De tinte autobiográfico, varios de sus textos tematizan, reescriben y ficcionalizan la historia nefasta de la dictadura y los desarraigos a los que se vio obligada. El francés, lengua de su nuevo lugar de residencia, es el idioma elegido para sus textos. El lenguaje, hogar del escritor, "casa del ser", como lo sostendría Heidegger y según reflexiones rayanas en lo romántico, se erige como una cuestión visceral del exilio cuando el idioma de la nueva tierra es también extranjero. Si en lo peritextual y de manera externa a las novelas la autora ha reflexionado sobre la lengua elegida para la escritura, en el interior mismo de los textos la reflexión sobre aquella, tanto la materna como la adoptada durante el destierro, se convierten en motivo transversal a las historias narradas.

El presente trabajo estará guiado por la intención de analizar diferentes formas en las que ingresa la problemática del lenguaje en La casa de los conejos (2007). La novela se configura como territorio de reflexión implícita o explícita, latente o patente, acerca de la lengua. Puede encuadrase en la narrativa sobre la última dictadura y en la autobiografía novelada. ${ }^{3}$

${ }^{2}$ En este sentido, la escritura puede dimensionarse como una de las formas de duelo, en cuanto elaboración del trauma (LaCapra, Escribir).

${ }^{3}$ No se trata de un intento de encasillamiento de la novela. En efecto, en lo general resultan más productivas las lecturas en los límites e intersticios de los géneros o en lo que un texto puede tener de cada género. Sin embargo, la clasificación es a los fines de mejor poder señalar y estudiar los ejes planteados para el trabajo (sean del enunciado, de las estrategias de la enunciación o del contexto). Pero quiere dejarse en claro que no se cree en una clasificación 
El régimen castrense está presente ora como tema y acción potencial en un futuro respecto del presente de la enunciación, ora en tanto núcleo actancial. El texto reconstruye parte de la historia del país, vivida por la autora durante su niñez. Se trata de un relato de infancia que presenta la mirada y la vivencia de una niña sobre el período de violencia política que precedió a la dictadura, sobre el régimen militar mismo y sobre el exilio, cimentándose en el procedimiento rector de cruces e intersecciones entre historia y ficción y reconstruyendo, entonces, la historia desde su ficcionalización. Se da una interacción entre las historias de vida mínimas y la macrohistoria. Por otra parte, la sustancia textual opera con material autobiográfico $^{4} \mathrm{y}$, si bien no se trata de una autobiografía en sentido estricto, puede rastrearse parte de la biografía de la escritora en el relato. Por empezar, la protagonista $^{5}$ de La casa de los conejos se llama Laura.

En un vaivén entre el pasado y el presente ${ }^{6}$, entre una Laura niña y la ya adulta, el texto relata la historia de la llamada casa de los $\operatorname{conejos}^{7}$ en la que vivió

taxativa de los textos. Como lo expresó Mijaíl Bajtín, los géneros fueron creados por los dioses para que el hombre los transgrediera (1986).

4 En su libro Memoria y autobiografía, Leonor Arfuch resalta la relevancia de lo autobiográfico respecto de las escrituras y la narrativa vinculada al relato de los hechos traumáticos de la dictadura en las últimas décadas, "donde las narrativas testimoniales y autobiográficas han sido esenciales para la elaboración de la experiencia de la última dictadura militar" (81). No obstante, señala a propósito del tema y la cuestión genérica: "La impronta biográfica y testimonial de estas narrativas, que dan cuenta de experiencias vividas y aluden a hechos y personajes reales, no debe hacer olvidar la ya clásica distinción entre autor y narrador, que la teoría literaria instauró hace décadas y que comprende incluso a la autobiografía aunque ésta juegue a identificar ambas figuras" (81). En cuanto a esta porosidad en los límites genéricos de las escrituras del yo en los textos memorialísticos, Patricia Flier señala lo siguiente: "Cuando los años empiezan a pasar y las imágenes del suelo natal se vuelven más difusas aparecen los estudios anclados en la larga memoria. Con el trascurrir del tiempo, los recuerdos del país de origen se van difuminando. Ante esta situación, los narradores trasterrados emprenden la tarea de recuperar su pasado en un ejercicio a medio camino entre la autobiografía y la autoficción, en el que la reconstrucción de la saga familiar cobra enorme relevancia" (231).

${ }^{5}$ Una característica recurrente en los textos de la serie narrativa sobre la dictadura argentina es la configuración de los personajes como protagonistas de sus historias de vida, microhistorias, situados en una historia mayor, a nivel macro. Los personajes se construyen en la intersección de estos espacios, por lo que de alguna manera serían protagonistas de sus historias, pero a la vez, testigos de la gran historia. En este sentido, se sitúan en los límites entre las categorías de protagonistas y testigos.

${ }^{6} \mathrm{La}$ alternancia de tiempo pasado y presente es una estrategia discursiva recurrente en las novelas sobre la última dictadura, en un gesto por el que se lee, entre otras cosas, la pervivencia del pasado en el presente. Así lo entiende Karen Saban: "La inquietud acerca del tiempo es, pues, el denominador común de estos relatos [Los planetas de Sergio Chejfec y La casa de los conejos 
Alcoba durante algún tiempo de su infancia: se trató de una residencia que aparentemente se dedicaba a la cría de dichos animales, pero que en verdad, de manera oculta, funcionaba como imprenta clandestina en donde se imprimía la revista Evita Montonera. Diana Teruggi (personaje histórico al cual está dedicado el libro y quien se cree que es a la vez la interlocutora que plantea el texto) y su compañero fueron los habitantes permanentes de ese lugar. Un operativo represivo de la dictadura arremetió contra la casa y contra quienes se encontraban allí en ese momento. Los sucesos acontecidos en la casa de los conejos son reconstruidos y ficcionalizados en la novela. Se imbrican el nivel textual y de los paratextos, lo ficcional y los datos de la historia argentina: ${ }^{8}$ por un lado, desde lo paratextual, el libro está dedicado a Diana Teruggi. Por otra parte, dentro de la trama del texto, una tal Diana carente de apellido, pero a quien podría identificarse con la misma Teruggi, es la interlocutora de Laura. Lo cierto es que

de Laura Alcoba] y tiene un carácter doble. En primer lugar obedece a la plena actualidad del pasado en el presente [...] En segundo lugar, la angustia relativa al tiempo tiene que ver con su polo opuesto. Ya no se trata de desembarazarse de una historia tortuosa, sino del miedo al paso del tiempo y al debilitamiento de la memoria" (1-2).

7 Actualmente, "la casa de los conejos", llamada "Casa Mariani-Teruggi" por los apellidos de quienes fueran sus habitantes y situada en la ciudad de La Plata, provincia de Buenos Aires, es un espacio para la memoria. En la novela se relata de la siguiente manera: "Acompañada por Chicha, casi treinta años después, en La Plata, pude así volver a ver lo que queda de la casa de los conejos. Hoy una asociación se ocupa de ella y trata de convertirla en un espacio de recordación" (La casa 127). En otro aspecto, María Isabel Chorobik de Mariani, más conocida como "Chicha", todavía busca a Clara Anahí, su nieta apropiada el día en el que la casa fue brutalmente atacada en un operativo del sistema represivo dictatorial y en el cual murieron quienes se encontraban allí en ese momento.

${ }^{8}$ A esta distinción entre los sucesos ficcionales y los históricos (diferenciación nunca clara ni tajante) viene a añadirse otro desdoblamiento respecto de estos últimos, atravesados por el concepto de narración. Una cosa son los acontecimientos en sí mismos y otra, los sucesos reconstruidos por medio del relato, cuestión señalada por Hayden White, quien distingue los "acontecimientos" de los "hechos" y la labor del historiador que media entre ellos: "Los historiadores transforman la información sobre 'acontecimientos' (events) en 'hechos' (facts) que sirven como materia para sus argumentos. Los acontecimientos ocurren o se dan; los hechos son constituidos por la subsunción de los acontecimientos bajo una descripción, es decir, por actos de predicación" (18). Esto es lo que lleva al autor a considerar que el discurso histórico no difiere en lo esencial del literario (65), conclusión que es discutible y que, en efecto, ha sido debatida y puesta en cuestión, pero que no invalida la verdad de las premisas de las que parte para su razonamiento. Arfuch se refiere a Hayden White, uno de los exponentes del giro lingüístico, resaltando que "el autor postulará para la Historia, con mayúscula, no ya un papel meramente representativo de los acontecimientos del pasado -que estarían, cual originales, en algún medio neutral-, sino uno narrativo y, por ende, configurativo: la historia (¿cuál historia?) será también un resultado de la narración" (75). 
esta historia sucedida en la Argentina de los años de plomo está escrita, al igual que el resto de la producción de la autora, en francés: es el idioma que elige para la escritura. Cercano a esto se halla el hecho de que, como lo señala Anna Forné, Alcoba escribe desde los márgenes, en tanto que escribe desde el exilio memorias de su infancia durante el último régimen castrense en Argentina (69). Y esto plantea ya algunos interrogantes.

“¿En qué lengua escribir memorias, cuando no hubo una lengua materna autorizada? ¿Cómo decir ‘yo me acuerdo’ que valga cuando hay que inventar la lengua y el yo [je], inventarlos al mismo tiempo, más allá de ese despliegue, ese desencadenamiento de la amnesia que desató la doble interdicción?" (Derrida 30) (Destacado en el original). Esta pregunta se formula Jacques Derrida en $E l$ monolingüismo del otro y es que el exilio siempre imprime su signo en la lengua (aun cuando el idioma del lugar que recibe es el mismo, nunca es idéntico ya que existen siempre variedades dialectales). Para Bordelois, "los exiliados saben qué riqueza entrañable y profundamente añorable representa la lengua madre" (136). Los modos de dimensionar la propia lengua (o inclusive la variedad dialectal) cuando ha habido exilio se plantean de múltiples maneras: puede haber negación a aprender el nuevo idioma, extrañamiento ante la propia lengua o, inclusive, olvido. Juan Gelman, en reportaje con Mona Moncalvillo, expresa: “[...] Pienso que esto le pasó a la mayoría, incluso había gente a la que su negación del exilio la llevó a no aprender el idioma a pesar de estar viviendo durante dos o tres años, hasta que empezó a deshacer las valijas del alma” (Boccanera 49). ${ }^{9}$ Y la relación

9 Jorge Semprún, en La escritura o la vida, plantea una relación dual, ambigua con la lengua: "Y también había numerosos soldados procedentes de Nuevo México, cuyo español melodioso me encantaba. O me perturbaba: que la lengua de mi infancia fuera la de la libertad, no sólo la del exilio y el recuerdo angustiado, resultaba perturbador" (117). Cristina Siscar cuenta su experiencia de extrañamiento ante el propio idioma: "El presente se parecía a una hoja en blanco: no se podía dar nada por sentado, había que redescubrir el mundo y crear nuevas relaciones a cada paso. Y el problema del idioma también revelaba un aspecto positivo. El bilingüismo me hizo adquirir una extraña conciencia lingüística: me había vuelto hablante y escucha a la vez, escucha de mí misma. La lengua extranjera se alzaba a cada momento como una evidencia material, un bloque entre la realidad y yo. Y lo mismo empezó a pasarme con mi propia lengua, que era objeto de observación en la intimidad y de juego con los amigos. ¿Qué era eso que se resistía a la pura comunicación? Había que redescubrirla en su música, su arbitrariedad y su misterio. Cuando volví, me chocaba que la gente hablara tan naturalmente en 
inversa también es posible: sujetos que adoptan la lengua del exilio, como es el caso da la escritora en cuestión.

Puede pensarse que Alcoba escribe en francés por una cuestión pragmática: reside en Francia y es allí en donde edita y publica sus textos. Sus novelas operan un cruce de categorías entre la literatura francesa y la argentina. Esto se advierte y vale, sobre todo, para La casa de los conejos: por el hecho de estar escrita en francés, bien podría situarse dentro de la francesa; por los recursos, procedimientos y operatorias discursivas, puede encuadrarse en el marco de la serie narrativa sobre la dictadura en Argentina, lo cual nos desliza a hablar de literatura argentina. Las condiciones de producción motivan ciertas reflexiones sobre la recepción.

En una primera instancia, si el lector es uno de habla francesa, entonces la autora concibe la narrativa sobre la dictadura argentina y el terrorismo de Estado más allá de los límites del receptor argentino -al que podría considerarse, tomando las categorías de Umberto Eco, como un lector modelo- o incluso latinoamericano. Puede dimensionarse el texto como un intento de dar a conocer ciertos hechos funestos vividos en la Argentina de mediados los años setenta y entrados los ochenta. Un dato que adquiere relevancia es que, no obstante el público primero al que se dirige (un lector francés o que al menos conoce la lengua), el texto opta por eludir cualquier nota aclaratoria de nombres, sucesos o fechas históricas, como más adelante se muestra con las propias palabras de la autora. Una segunda cuestión que se desprende de escribir sobre estos temas reside en contribuir a la memoria sobre el pasado traumático. Al comienzo, Laura, el sujeto de la enunciación que puede vislumbrarse como una proyección en espejo (siempre deformante) o una figuración de la voz autoral esgrime: "Voy a evocar toda aquella locura argentina, todos aquellos seres arrebatados por la violencia. Me he decidido, porque muy a menudo pienso en los muertos, pero también porque ahora sé que no hay que olvidarse de los vivos" (La casa 12). La adaptación" (Boccanera 54). 
opción por contrarrestar el olvido se traduce en un intento de constituir el relato y la escritura en medios para la memoria individual e histórica. De este modo, lo que sucede en el nivel ficcional es sintomático de la novela como objeto semiótico dotado de significaciones particulares: el personaje narrador le escribe a Diana con el fin de informarle sobre lo sucedido, como lo declara explícitamente, pero también para recordar ella misma, a los efectos de hacer memoria para ella y para otros. El ejercicio del relato en el interior del texto replicaría el contar como forma de transmisión y de memoria en el exterior de la novela. En esta dirección, escribir se transforma en mecanismo para hacer memoria en, al menos, dos sentidos: por un lado, dentro del universo ficcional, el acto escritural conduce al sujeto a rememorar en la misma acción de la escritura, tratándose de una memoria, en principio, individual; ${ }^{10}$ por otro, en la esfera extraliteraria, el arte y la escritura sobre estos sucesos traumáticos conllevan inherentemente el ejercicio de la memoria. Como señala el juez Martín Lozada a propósito de lo memorialístico y la esfera artística:

Un proyecto genocida no se define únicamente por el asesinato de las personas, sino también por la destrucción para los sobrevivientes de la posibilidad misma de transmitir. ${ }^{11} \mathrm{Y}$ es aquí donde entra a jugar un

${ }^{10}$ Esto, asimismo, se vincula con la idea de la escritura como duelo: duelo por la muerte de un sujeto o duelo por la situación traumática, por un hecho. Arfuch señala las relaciones entre narración, duelo, memoria e historia: "Si de algún modo las narrativas del yo nos constituyen en los efímeros sujetos que somos, esto se hace aún más perceptible en relación con la memoria en su intento de elaboración de experiencias pasadas, y muy especialmente de experiencias traumáticas. Allí, en la dificultad de traer al lenguaje vivencias dolorosas que están quizá semiocultas en la rutina de los días, en el desafío que supone volver a decir, se juega no solamente la puesta en forma -y en sentido- de la historia personal, sino también su dimensión terapéutica, -la necesidad de decir, la narración como trabajo de duelo- y fundamentalmente ética, por cuanto restaura el circuito de la comunicación -en presencia o en la 'ausencia' que supone la escritura- y permite escuchar, casi corporalmente, con toda su carga significante en términos de responsabilidad por el Otro. Pero también permite franquear el camino de lo individual a lo colectivo: la memoria como paso obligado hacia la Historia" (76). La crítica concluye: "La creación artística deviene así una de las formas del trabajo de duelo" (81).

${ }^{11}$ Algo semejante postula el sociólogo Daniel Feierstein por medio de su concepto de "realización simbólica": "[...] una vez llevado a cabo el exterminio, una vez fundado en la destrucción -a través del terror y el aniquilamiento- de las relaciones de reciprocidad entre pares, el genocidio reorganizador continúa (y debe continuar) su acción a posteriori por medio de lo que he llamado 
elemento fundamental: la memoria. Tanto los individuos como los grupos necesitan conocer su pasado, puesto que la conformación de su propia identidad depende de ello. No existe pueblo o comunidad de individuos sin memoria común, recuerdos compartidos e hitos referenciales. (Lozada 53)

En este sentido, más adelante en sus reflexiones, el magistrado dimensiona el arte como una de las esferas que contribuyen a esa memoria.

La novela trasciende los límites espaciales del lugar principal en el que se enmarcan sus hechos y va más allá de la memoria en el plano de la ficción para elaborar de igual manera una por fuera de aquel. Pero también puede entenderse la constitución de la memoria en otro sentido, ahora por asociación, por relaciones paradigmáticas, activando otros horizontes de lectura: al tratar de sucesos traumáticos a nivel histórico y colectivo, en los lectores franceses son plausibles de activarse experiencias similares, que hacen a la propia historia de Francia:

Ese día, estoy convencida, se corresponde con un viaje que hice a la Argentina, en compañía de mi hija, a fines del año 2003. En los mismos lugares, yo investigué, encontré gente. Empecé a recordar con mucha más precisión que antes, cuando sólo contaba con la ayuda del pasado. Y el tiempo terminó por hacer su obra más rápidamente que lo que yo había imaginado jamás: a partir de entonces, narrar se volvió imperioso. ( $L a$ casa 12$)$

En el anterior fragmento se figura lo que podría verse como cierto aspecto y torsión del motivo del viaje. Éste es el causal de la narración: con él se inicia la

mecanismos de realización simbólica. La eliminación y negación material de los cuerpos que representan esas relaciones de autonomía no termina de realizarse, no termina de definirse, si no hay una posterior negación simbólica de los mismos. Lo que aparece en los discursos posteriores al genocidio es toda una lógica de construcción de la inexistencia de esa relación social, ni siquiera como memoria" (128). 
escritura. Se trata de un viaje que consiste en desandar el camino del exilio o, más bien, en posicionarse en el espacio en el que se originó. La situación en el espacio geográfico se ve transmutada en la situación en la temporalidad: en una ecuación en la que se desconfiguran las categorías tempo espaciales, el sitio del exilio viene a identificarse con el tiempo pasado. Se trataría, en términos de Mijail Bajtin, de un "cronotopos" en el cual la patria desarraigada suscita el recuerdo, la memoria y, en última instancia, la narración del pasado de la historia reciente. Se da forma así, subrepticiamente, a la noción de territorialización de la memoria, a la idea de que las topografías y los objetos son propicios al recuerdo ${ }^{12}$. Argentina se presenta entonces desde el lenguaje de lo material, de lo que los lugares hablan y callan.

Mientras que en el comienzo de la novela el sitio que se nombra explícitamente es Argentina, hacia el final se menciona específicamente la casa de los conejos, en La Plata. El recurso es nuevamente el de la territorialización del recuerdo. Y ante las emociones que éste suscita, se produce una reflexión no acerca de una lengua en particular, sino sobre el lenguaje en general: "No existen palabras para la emoción que me invadió cuando descubrí, en cada cosa recordada, las marcas de la muerte y la destrucción” (La casa 127). El lenguaje, ahora, se reviste de carencia: no resulta suficiente para expresar lo propio del terreno de los afectos. Se da una suerte de desplazamiento, de hiato imposible de zanjar entre las palabras y su referencia, entre la designación y la cosa designada. Michel Foucault plantea que lo visto no reside jamás en lo que se dice, que las palabras no se asemejan a las cosas que nombran, que el lenguaje porta en sí mismo el principio de proliferación y que todo discurso lleva consigo silencios (27, 54, 58, 313). Esta discontinuidad se ve acentuada para las historias atravesadas por el trauma y escritas por el sino trágico del horror, como lo es la de "muerte y destrucción" de la última dictadura. El trauma provoca un vacío de simbolización, una carencia de palabras, un hueco en el lenguaje, en tanto que la

12 Anne Huffschmid sostiene (parafraseando a Karl Schlögel y su libro "En el espacio leemos el tiempo") que "la memoria se deja "leer en el espacio"” (15). 
experiencia traumática misma se halla fuera de lugar, ajena al universo discursivo que permitiría aproximarse a la experiencia (Insúa 26): "Frente al límite de la experiencia impensable, el lenguaje requiere un 'más allá de él'. Las palabras no alcanzan para nombrar lo que hay que testimoniar" (30) puesto que "la lógica concentracionaria apunta contra la dignidad humana, contra la esencia de lo humano, la palabra" (Rousseaux 35). Y ante esto Miguel Dalmaroni subraya: "En el caso de estas novelas" se instala una cuestión: "la convicción cultural de que eso que en efecto sucedió será siempre excesivo respecto de cualquier lengua narrativa que intente decirlo, funciona como un mandato inapelable" (La casa 168). En este sentido, cuando "ya bien avanzado el período democrático", el padre le entrega un libro a su hija en el que se menciona la casa de los conejos (Los del '73. Memoria montonera de Gonzalo Chaves y Jorge Omar Lewinger), Laura comenta: "No dijo nada más. En verdad, nos cuesta mucho hablar de todo aquello" (La casa 124). Sin dudas, la dimensión del horror es uno de los elementos que contribuyen a la dificultad de hablar sobre el tema. Ya antes, el horror es bordeado desde un signo de puntuación tan vago y a la vez harto elocuente como son los puntos suspensivos:

Cuando Diana me propuso subir con ella a la furgoneta gris para acudir a una cita y entregar algunos periódicos, sentí una gran alegría y, sobre todo, un inmenso alivio. Una trampa; eso era esta casa. Cuando pienso en mi madre, emparedada detrás de los conejos, haciendo girar las rotativas... Pero aquel día, felizmente, Diana y yo salimos un poco. ( $\mathrm{La}$ casa 110)

El solo hecho de imaginar lo que podría haber sucedido hace que Laura deba detener el relato y que esa potencialidad se complete por sí sola en la suspensión de los puntos. La dimensión del potencial horror no puede ni quiere ponerse en palabras. Tal dificultad se ve profundizada en el caso de Laura por el temor al qué dirán, a la mirada de los otros sobre su relato de los hechos. Así, al 
comienzo de la narración, interpela a su interlocutora, pero dirigiéndose también, indirectamente, al lector:

Te preguntarás, Diana, por qué dejé pasar tanto tiempo sin contar esta historia. Me había prometido hacerlo un día, y más de una vez terminé diciéndome que aún no era el momento. Había llegado a creer que lo mejor sería esperar a hacerme vieja. La idea me resulta extraña ahora, pero durante largo tiempo estuve convencida. Debía esperar o quedarme sola, o casi. Esperar a que los pocos sobrevivientes ya no fueran de este mundo o esperar más todavía para atreverme a evocar ese breve retazo de infancia argentina sin temor de sus miradas, y de cierta incomprensión que creía inevitable. Temía que me dijeran: “¿Qué ganás removiendo todo aquello?". Y me abrumaba la sola perspectiva de tener que explicar. La única salida era dejar hacer el tiempo, alcanzar ese sitio de soledad y liberación que, así lo imagino, es la vejez. Eso pensaba yo, exactamente. (La casa 11)

La dificultad del relato de lo ominoso, además de estar acentuada por el temor a ser juzgado, se profundiza por un mandato de silencio inapelable del que fuera presa Laura cuando era pequeña, en el mismo momento de los hechos. En más de una oportunidad, la narradora-personaje se refiere a este mandato:

Del altillo secreto que hay en el cielorraso no voy a decir nada, prometido. $\mathrm{Ni}$ a los hombres que pueden venir y hacer preguntas, ni siquiera a los abuelos. Mi padre y mi madre esconden ahí arriba periódicos y armas, pero yo no debo decir nada. La gente no sabe que a nosotros, sólo a nosotros, nos han forzado a entrar en guerra. No lo entenderían. No por el momento, al menos. (La casa 16-17) 
En un presente que recupera el tiempo y la mirada de la infancia, Laura expresa su deber de silencio, lo cual utiliza como medio para introducir la descripción de la tortura vista desde su visión infantil:

A mí ya me explicaron todo. Yo he comprendido y voy a obedecer. No voy a decir nada. Ni aunque vengan también a casa y me hagan daño. Ni aunque me retuerzan el brazo o me quemen con la plancha. Ni aunque me claven clavitos en las rodillas. Yo, yo he comprendido hasta qué punto callar es importante. (La casa 16-17)

Las modulaciones del silencio, en este caso como imperativo en el tiempo pasado no dejan de tener sus resonancias en un relato presente que se construye, como contrapartida, a la manera de una necesidad: necesidad de contar, necesidad de recordar a quienes ya no están, necesidad, en fin, de memoria individual pero también colectiva.

¿Qué palabras utilizar, cuáles no, qué recursos emplear, de qué manera contar una historia acontecida en el mismo seno del horror? El lenguaje no es solamente un medio de contar la(s) historia(s) sino que es también, y en parte, la historia misma. En esta dirección, al emplear palabras en castellano en el original francés, se produce una disrupción en el texto de Alcoba, hiato que remeda la disrupción del trauma: el empleo de una y otra lengua da cuenta de la dificultad del relato del horror, en tanto que la autora debe recurrir a ambas lenguas y así y todo ninguna de ellas alcanza a dar cuenta de él. La disrupción en el plano del lenguaje es homóloga a la disrupción que provoca el trauma en el nivel de la vivencia. Se da una condición de "entre lenguas", en la cual reside el exceso significante de lo traumático: no es ninguna de ellas en las que puede registrarse el horror, sino en el intersticio, en el espacio intermedio entre ambas, en ese hueco que se asocia al silencio y a lo innominable. Hay un vacío que ninguna de las dos lenguas alcanza a llenar. Como sostiene Daniel Moyano: el "escritor exiliado, que 
necesita reconstruir con palabras una patria, pero también inventar la que todavía no existe" (s/p. - versión digital).

Retomando la pregunta del párrafo anterior, cabe resaltar que existen términos que no tienen equivalentes en otros idiomas. Más aún, hay ciertos lexemas que ni siquiera están registrados en el diccionario del propio. Ante este problema se enfrenta el sujeto de la enunciación: la particularidad de "la casa de los conejos", aquella obra de ingeniería por la que ella puede dejar de ser tal para convertirse en una imprenta clandestina, es designada por un término lingüístico no registrado en el diccionario de la lengua española (sí con otras acepciones, pero no con el significado de la jerga militante con que se reviste en el caso en cuestión). Se trata de la palabra embute, la cual funciona para el personaje a la manera de la metonimia, en cuanto que su sola mención evoca toda una época en su vida; no sólo rememora un espacio físico sino también un tiempo de su historia $^{13}$.

Cierta zona del lenguaje materno convoca y se une indisociablemente al recuerdo de los hechos pasados. Asimismo, el siguiente fragmento diseña toda una cartografía del recuerdo, trazada por ciertas palabras claves de un campo semántico que se nuclean en torno a él y a la lengua materna. Intervienen dos clases de palabras: por una parte, los sustantivos "memoria", "idioma español", "habla argentina", "pasado", "palabras", "término"; por otra, los verbos que hacen referencia a una acción de búsqueda y reconstrucción, por medio de esa palabra de la lengua materna, del pasado y el recuerdo: "hurgar", "encontrar", “investigar", "reencontrar", "restituir":

Cuando pienso en esos meses que compartimos con Cacho y Diana, lo primero que viene a mi memoria es la palabra embute. Este término del idioma español, del habla argentina, tan familiar para todos nosotros durante aquel período, carece sin embargo de existencia lingüística

13 El término embute es desconocido para muchas personas de Argentina, gente incluso contemporánea a la época de la Triple A y la dictadura. Se trataría más de un término perteneciente a cierta "jerga" particular. 
reconocida. Desde el mismo instante en que empecé a hurgar en el pasado -sólo en mi mente al principio, tratando de encontrar una cronología todavía confusa, poniendo en palabras las imágenes, los momentos y los retazos de conversación que habían quedado en mí- fue esa palabra el primer elemento sobre el que me sentí compelida a investigar. Ese término tantas veces dicho y escuchado, tan indisolublemente ligado a esos fragmentos de infancia argentina que me esforzaba por reencontrar y restituir, y que nunca había encontrado en ningún otro contexto. (La casa 47)

En cada oportunidad en que se la incluye, la palabra aparece escrita en bastardillas. Ya desde el aspecto gráfico se produce entonces una disrupción con el resto del texto. Por la diferencia (análoga, como se dijo antes, a la disrupción que la excepcionalidad del trauma provoca en la normalidad de la vida cotidiana) que suscita, cada mención de "embute", es decir, el término puntual, convoca la lengua materna del sujeto y consecuentemente, recrea una atmósfera lingüística latente en la escritura. El término (que pertenece al idioma de la infancia, anterior al exilio) que evoca metonímicamente una etapa en la vida del personaje $y$, con ello, un período histórico, no tiene traducción a otra lengua y aun constituye un lenguaje particular dentro de la propia. Por operación de desplazamiento metonímico, materializado en el término embute, es la lengua materna, aquella en la que vivió los hechos, la que mejor le permite recuperarlos en forma de recuerdos, evocarlos en su afán de hacer memoria y describirlos en su intento por reconstruir y dar a conocer parte de una historia: "No podemos volver a todos los pliegues de estos enunciados clásicos. Como la 'solicitud maternal [que no tiene reemplazo]', decía Rousseau, nada puede reemplazar, confirma Arendt, a la lengua materna" (Derrida 51). La lengua encarna una particular visión de mundo, al tiempo que estructura las formas de pensamiento, como asevera la conocida hipótesis de Sapir-Whorf y que reafirma Steiner (Lenguaje y silencio). Simultáneamente, la palabra "embute" es en otro aspecto metáfora y metonimia 
de la historia a contar. Mientras que el significado que se le atribuyó en la época de la dictadura no está registrado en el diccionario, la historia que se rescata es una no escrita en las páginas oficiales de la época. El relato y la ideología de la miltancia, así como todo relato opositor, intentaron ser silenciados y borrados de la historia, subsumidos y manipulados por el relato hegemónico. Es en este sentido que el término no registrado y, por extensión, la lengua, opera como metonimia de la historia, desplegando una constelación de significados en la que la lengua materna adquiere un lugar central. Se trata de un gesto de rescate de lengua e historia:

El lugar de la escritura como memoria, como otras de las formas de luchar contra el silencio, el deseo de reconstruir desde los escombros, de arrebatar la palabra a quienes destruyeron los cuerpos, llenar el vacío, y escribir en la lengua que aún les queda a los argentinos después de la tortura, rehacerse desde la lengua privada, individual, la lengua de cada escritor, combatir al Español como el símbolo de la Madre Patria Argentina, su Religión, su Unidad Nacional, su Lengua Madre, una lengua que ha pretendido desaparecer a quienes la hablan de manera diferente, a quienes la usan de manera desviada, fragmentaria, escindida, balbuciente. (Lorenzano 12)

Este término que no figura en los registros de la lengua escrita hace trazar a Laura un recorrido de búsqueda de significado: a un significante particular, no se le encuentra significado registrado, y en esta dirección vuelve a verse cómo la palabra es metonimia de una historia que ha sido solapada, silenciada por, entre otros, el mandato de silencio que pesaba sobre el personaje por indicación de los mayores, una autocensura a su vez motivada por la censura y persecución imperantes en la época. La narradora-personaje no encuentra la definición de esta palabra. Este camino de búsqueda de significado podría homologarse con la búsqueda de una explicación de lo sucedido, al tiempo que se homologa, aunque 
en una dirección inversa, con la búsqueda de palabras para definir el horror: si para el significante "embute" se desea encontrar un significado, para el sentido del horror se buscan significantes que puedan definirlos, conceptos y tramas narrativas que sean capaces de recubrir la experiencia del horror. Ninguna de las dos búsquedas podrá completarse: “Consulté en principio los diccionarios con que contaba en casa: ni un rastro de embute. Durante meses, interrogué a cuanto hispanohablante tuve ocasión de cruzar en mi camino: ninguno de ellos conocía la palabra" (La casa 47). Y su indagación continúa: escribe un correo para consultar a la Real Academia Española, busca en Internet, siempre infructuosamente. Llega a la conclusión de que “"Embute’ parece pertenecer a una suerte de jerga propia de los movimientos revolucionarios argentinos de aquellos años, más bien anticuada ya, y visiblemente desaparecida" (50). Esta última palabra tiene sus ecos en la dimensión más horrorosa e inaprensible, por medio del lenguaje, de la dictadura: los desaparecidos (en efecto, ¿cómo definirlos?). Tampoco encuentra la palabra en la casa de los conejos (lo que para ese entonces está próximo a convertirse en un "espacio de recordación”, como se dice en la novela), una vez que va a visitarla en el viaje que motiva su escritura: "En ese lugar, aún puede distinguirse el emplazamiento de la imprenta clandestina. Una placa explicativa de qué servía este extraño espacio estrecho, encerrado entre dos muros, hoy en gran parte devastados. Pero la palabra embute no aparece, ni siquiera entre comillas" (La casa 127). Esos silencios son nombrados en el texto de Alcoba. Mas si por un lado se mencionan (como es el caso de "embute"), por otro no terminan de explicarse, como metáfora de un horror inefable. Es por esto, en parte, que en su reseña a la novela, Gilda Waldman Mitnick señala que "la narradora mira en un permanente movimiento entre el 'afuera' y el 'adentro', el 'nosotros' y el ‘ellos', lo visible y lo invisible, el silencio y la palabra” (158).

Dice Barthes: "Notar la paradoja: el silencio no se vuelve signo sino cuando se lo hace hablar, si se lo acompaña de una palabra explicativa que da su sentido" (73). En esta dirección, contar la historia en Alcoba significa también poner en escena los silencios, en cuanto que al decir y a lo dicho se le adosa una 
cuota de lo indecible (aquello que no puede ponerse en palabras) y de lo no dicho (aquello que no quiere ponerse en palabras). Así, por ejemplo, un término central en el texto como lo es "embute" 14 , es mentado y vuelto a nombrar en diversas oportunidades, sin jamás explicar su significado: “"Embute' se vuelve para el lector una palabra tan obsoleta como misteriosa, y quienes no comparten con ella la experiencia de aquellos años deben adivinar en la trama de la novela el significado de una palabra que no dice nada por sí misma" asevera Victoria Daona (s/p. - versión digital). De esta manera el universo discursivo de la novela se carga de un silencio, una omisión en cuanto a la definición del concepto. Dicha palabra funciona como metonimia, pero también como símbolo en el sentido que le atribuye Blanchot a esta figura, ${ }^{15}$ símbolo en el que el significado queda oculto y por el cual se cuenta una parte, mientras que queda un resto sin decir, sin ser referido. Acaso pueda leerse ese resto como síntoma de la imposibilidad de nombrar el horror por completo. Refiriéndose a las víctimas del genocidio nazi en su libro La escritura del desastre, el autor advierte sobre un lenguaje otro:

Estos nombres, en el campo devastado, asolado por la ausencia que los precedió y que llevarían adentro si, vacíos de toda interioridad, no se irguiesen exteriores a sí mismos (piedras de abismo petrificadas por el infinito de su caída), parecen ser los restos, cada uno, de un lenguaje otro, a la vez desaparecido y nunca pronunciado, cuya restauración no pudiéramos intentar a menos de reintroducirlos en el mundo o exaltarlos hasta un sobremundo del cual, en su soledad clandestina de eternidad, no

\footnotetext{
${ }^{14} \mathrm{Si}$ para muchos de los lectores argentinos resulta desconocido el término, cuánto más para un lector de lengua francesa. En este sentido, la ausencia de definiciones del término no hace más que resaltar su condición de metonimia e inclusive símbolo, su carácter de palabra que evoca otra cosa.

15 Blanchot retoma el significado de símbolo de Humboldt: "Por último, Humboldt emplea la palabra símbolo más o menos como Hegel: mediante el símbolo se torna decible o mostrable lo irrepresentable: 'El símbolo tiene el poder de convidar y de constreñir la mente a permanecer cerca de la representación' de lo que no se representa -lo trascendente puro. En otra parte, Humboldt habla de "la diferencia irreductible entre el concepto y el elemento fonético" ( $L a$ escritura 94).
} 
CATEDRAL TomadA: Revista de crítica literaria latinoamericana / Journal of Latin American Literary Criticism Configuraciones de la lengua en La casa de los conejos de Laura Alcoba.

pueden ser más que la inestable interrupción, la invisible ocultación. ( $\mathrm{La}$ escritura 57)

Pero no solamente hay un lenguaje no pronunciado que subyace y a la vez excede el que sí es articulado, sino que, como ya se adelantó con Levi, aun esa lengua pronunciada ha sido víctima de la violencia de los crímenes cometidos, como lo sostienen George Steiner (Lenguaje y silencio, Extraterritorial) o Elie Wiesel a propósito del genocidio nazi: “Auschwitz significa muerte, muerte total, absoluta, del hombre y de toda la gente, del lenguaje y de la imaginación, del tiempo y del espíritu" (Wiesel en Bettelheim 125). ${ }^{16}$

La palabra "embute" actualiza toda una constelación de significados, por relaciones asociativas, que remiten directamente a la violencia, aun cuando la novela guarde silencio sobre su significado y, más todavía, a causa de ese silencio. Como sostiene El mono gramático de Octavio Paz, "aquello que se dice en el lenguaje sin que el lenguaje lo diga, es decir (¿es decir?): aquello que realmente se dice (aquello que entre una frase y otra [podríamos decir, entre una palabra y otra, entre un morfema y otro], entre esa grieta que no es silencio ni voz, aparece) es aquello que el lenguaje calla (la fijeza es siempre momentánea)". En La representación prohibida, Jean-Luc Nancy lo plantea en términos de un signo como referente de otro: "los signos no son las presencias pero configuran otra presencia, las frases se alinean una tras otra sobre la página y al desplegarse abren un camino hacia un fin provisionalmente definitivo / las frases configuran una presencia que se disipa, son la configuración de la abolición de la presencia” (57).

Si en lo textual se formulan reflexiones sobre el idioma, específicamente, acerca de un lenguaje de época, en lo peritextual la autora cavila también sobre la lengua española. Se refiere, concretamente, a la imposibilidad de traducir ciertos

16 En Los hundidos y los salvados, Levi plantea reflexiones análogas al referirse a las pretensiones de estandarización del lenguaje por parte del fascismo: "Es obvia la observación de que donde se violenta al hombre se violenta también al lenguaje; y en Italia no nos hemos olvidado de las necias campañas fascistas contra los dialectos, contra los 'barbarismos' [...]" (92). 
términos a cualquier otra lengua. Por este motivo, determinados ítems léxicos -los que ella considera el núcleo de la novela- como ya se señaló, aparecen aun en la versión francesa original, en español. En una entrevista sobre La casa de los conejos, el entrevistador le pregunta a Alcoba qué papel jugó el francés en la escritura del texto, a lo que la ella contesta:

Llegué a Francia a los diez años, hice toda la secundaria allí, estudié Letras, es la lengua natural. Pero es verdad que en ciertos momentos, como yo trabajaba sobre una materia prima muy precisa -que eran esos recuerdos en Argentina-, afloraba el idioma en que habían ocurrido los acontecimientos y había cosas que no podía traducir, que no podía poner en francés, y en la versión de origen, cuando envié el manuscrito a Gallimard -no sabía qué iba a pasar-y surgió que me iban a publicar el libro, pensé que me iban a pedir que pusiera notas a pie de página, y lo sentía como algo que me molestaba pero tuve la gran suerte de que mi editor entendió completamente que era importante conservarlas en castellano, entonces hay lugares en el texto de origen que son más fuertes, y está esa palabra "azar". (Tejemaneje s/p)

Queda claro que Alcoba elige deliberadamente escribir en francés. Pero hay como una acción involuntaria por la cual, al recordar la historia pasada, surge, "aflora" la lengua materna casi sin que se la convoque. Hay un hecho fundamental aquí que conjuga lengua y experiencia, y es que ciertos acontecimientos, núcleo de esa historia (e Historia, así, con mayúscula), solamente pueden expresarse en la lengua en la que se vivieron. La autora reconoce no sólo que existen ciertos términos que mejor expresan su referencia en español, sino que no son plausibles de traducción. En efecto, señala que los lexemas que desea transcribir en tal idioma constituyen el núcleo de la novela. En la misma entrevista, se refiere a las palabras cruzadas que se transcriben hacia el final del libro: "as/zar", "Videla", "Isabel", "muerte", "arte", entre otras, y comenta lo siguiente: 
CATEDRAL TomadA: Revista de crítica literaria latinoamericana / Journal of Latin American Literary Criticism Configuraciones de la lengua en La casa de los conejos de Laura Alcoba.

Sí tiene [el crucigrama] un eco bastante siniestro. Las palabras cruzadas están en castellano en la versión de origen, porque para mí es el nudo, el centro del libro. Porque la pregunta que me obsesionaba, que quería volver a plantear escribiendo el libro es dónde se pasó la frontera entre los muertos y los vivos. La pregunta de haber estado tan cerca de gente que murió y por qué estar del lado de los vivos con todo el peso que eso significa [...]. (Tejemaneje s/p)

El crucigrama reúne las palabras que articulan el relato: el azar como (no)respuesta de los sucesos, Videla e Isabel como las imágenes visibles y de poder de la época en la que se enmarca la temporalidad pretérita de la novela (Triple A y golpe de Estado), la muerte como uno de los sustantivos esenciales que sintetiza el horror de aquel momento, el arte, término mediante el cual se asigna cierto lugar político a la novela, entendida, por ejemplo, como una forma de memoria o de relectura de la historia. ${ }^{17}$

La lengua materna es la opción elegida para la escritura de lo que la autora considera nodal en su libro. No se logra -ni tampoco se busca- el desprendimiento del idioma de la infancia. Por el contrario, siempre quedará algo que sólo podrá evocarse, expresarse, representarse, por medio aquél. En este caso, los términos que aparecen en español son doblemente disruptivos: por estar en castellano, pero también por ser parte de un gráfico (crucigrama). A propósito de lo disruptivo, entra en juego un segundo gran sentido de la combinatoria de lenguas en el interior del texto en el original: tal mecanismo puede leerse como el intento del sujeto por replicar su condición entre lenguas, en el intersticio entre ambas, esa extraterritorialidad a la que se refiriera Steiner (Extraterritorial). Si "toda la literatura puede ser considerada como una estrategia de exilio

${ }^{17}$ Mariela Peller, en su breve texto sobre la novela, analiza el significado de algunas de las palabras del crucigrama en relación con la postura de la autora como agente político al momento de escribir sobre el tema. Por su parte, Gilda Waldman Mitnick estudia también las palabras cruzadas, aunque tomando como centro uno de los términos nodales, a saber, "azar" (159). 
CATEDRAL TOMADA: Revista literaria latinoamericana / Journal of Latin American Literary Criticism Estefanía Luján Di Meglio

permanente" (33-34), la literatura del exilio vendría a redoblar esta situación extraterritorial. De esta forma, quedan delineadas dos grandes sentidos convertidos en dos grandes líneas rectoras de este trabajo- de un mismo signo, a saber, la amalgama entre lenguas: por un lado, tal mixtura en lo lingüístico significa la dificultad en el decir, en el poner nombre y articular un relato del horror, lo cual se vincula con el trauma de la dictadura; por otro lado, el significado de la mezcla de lenguas radica en situarse en ese espacio extraterritorial, lo que se relaciona con el trauma del exilio. Lengua y dictadura y lengua y exilio son dos grandes aspectos que estructuran la novela.

Finalmente, Alcoba enfatiza:

[...] digamos que las palabras cruzadas, el azar, que es lo que la nena se aferra a dejar inscripto (con una falta de ortografía: azar con "s", Isabel con “z”). El azar es lo que explica de cierto modo, la única explicación soportable. Para mí las palabras cruzadas son el corazón del libro. Y la palabra azar vuelve permanentemente. Cuando hablamos con Leopoldo Brizuela, que fue quien hizo la traducción, yo le decía que cada vez que aparecía la palabra azar en francés quería que quedara esa misma palabra en castellano porque es como un hilo. (Tejemaneje s/p)

En este sentido, el azar, una de las palabras que tejen el relato como hilo conductor, es la respuesta a lo inexplicable. El horror aflora en su relato, precisamente en el instante en el que se formula la falta de respuestas, es decir, cuando lo inexplicable y por tanto inefable se hace presente.

Así, se produce una mixtura entre ambas lenguas: el francés es el que en términos cuantitativos domina en el relato en el original, mientras que el español se emplea en palabras clave en el texto y lo recorre como hilo conductor de principio a fin. Elegir el español es una opción que se sitúa en el nivel de la enunciación y del enunciado al mismo tiempo: por una parte, el empleo de un término en otra lengua (es decir, diferente a la del idioma original de la novela) es 
un recurso en materia retórica, por lo que constituye una estrategia enunciativa a partir de la cual el español emerge sobre la superficie del lenguaje y tiñe su materialidad; pero por otro lado, y simultáneamente, se vincula con el contenido de la novela -el enunciado- desde el momento en el que el uso del español convoca una historia que no puede narrarse con mediación de otra lengua. Existen diversos modos en los que la lengua materna ingresa en el texto: bien por mención específica a ella, esto es, por medio de reflexiones sobre el español; bien por la inclusión de términos en español. Lo cierto es que constituye algo así como la esencia insustituible del relato y de la historia.

\section{Consideraciones finales}

El motivo de la lengua se instala como problemática y se muestra siempre presente en La casa de los conejos ya desde las condiciones de producción del texto. Estar escrito en francés no es un dato menor. El vínculo de la autora con su lengua materna adquiere los contornos de lo conflictivo desde el instante en el que (aunque no fuera más que por una cuestión meramente pragmática) se opta por el empleo de una lengua otra para el oficio de escritor. La escritura está directamente relacionada con la lengua que se elige para ella, y en esta dirección aquello que destaca es que los hechos narrados han sido vividos en una lengua diferente a la que da forma al relato. Lejos de estar ausente, la lengua en la que se vivieron los acontecimientos se hace presente como la manifestación del pasado en la narración, como eco que resuena y que signa la experiencia pretérita y la actualiza en el presente. La lengua materna emerge irreprimiblemente en ciertas zonas, en parte por ser el idioma en el que se vivieron los hechos. A un mismo signo (la duplicidad de los idiomas) se le atribuyen diversidad de significados. Dos de ellos se relacionan directamente con los motivos de la novela: la dictadura y el exilio. Así, el hecho de optar por dos lenguas para la narración de lo traumático del régimen militar sería síntoma de la imposibilidad de dar cuenta de ello por medio 
del lenguaje: ninguna lengua alcanza para definir el horror ni para ponerlo en relato. La escritura es a menudo el espacio simbólico que imaginariamente restituye, aún sin decir, lo no dicho, las ausencias, el vacío. Tal vacío se manifiesta en el espacio "entre lenguas". Al mismo tiempo, la coexistencia de dos lenguas estaría significando el lugar en el que se sitúa el escritor, el lugar del exilio: la extraterritorialidad, la no pertenencia manifestada en y por el lenguaje.

La narración misma deviene casi imperativo en el momento en el cual se visita el lugar de los hechos. La memoria se figura territorializada en el espacio que suscitan el recuerdo, la palabra y el lenguaje de una época pasada. A propósito de esto, se hace elocuente la inefabilidad de un lenguaje que no es capaz de hacer presa en la significación ante la experiencia de lo traumático. La dimensión de los hechos no puede ser subsumida por las palabras, por un lenguaje con palabras y estructuras que se ve excedido por la manifestación del horror. A esto viene a añadirse el que existen términos que no tienen traducción a otro idioma. La problemática de la carencia de la lengua materna -al menos en parteque conlleva el exilio se ve aquí redoblada por cuestiones idiomáticas y de la traducción. Es sintomático que una palabra ni siquiera registrada en la propia lengua (no con la acepción con que se la utiliza en la época y en cierta jerga militante) se activa en el texto y funciona como metonimia de este fenómeno de la (in)traducibilidad así como de una época y de unos hechos. La palabra "embute" opera al modo del desplazamiento metonímico por el cual su sola mención convoca una lengua toda - la lengua materna- y una época -la violencia de los años setenta-. Asimismo, el término adquiere los contornos de la metáfora en cuanto que su condición de estar ausente del registro lingüístico oficial es figurativo de la historia que está narrándose. Algo similar sucede con las palabras del crucigrama. Se trata de una historia no contada por las versiones oficiales, no registrada en la historiografía de la macrohistoria. 
CATEDRAL TomadA: Revista de crítica literaria latinoamericana / Journal of Latin American Literary Criticism Configuraciones de la lengua en La casa de los conejos de Laura Alcoba.

\section{Bibliografía}

\section{Corpus primario}

Alcoba, Laura. La casa de los conejos. 2008. Buenos Aires: Edhasa, 2010.

Traducción de Leopoldo Brizuela.

. Manèges. Petite histoire argentine. Paris: Gallimard, 2007.

\section{Bibliografía citada y consultada}

AA.VV. "Hijos del exilio-Tomar la palabra: hablan los hijos del exilio". Puentes. Año VII/número 21 (2007): 28-29.

(S/D). "Tejemaneje: Entrevista a Laura Alcoba". Apóstrofe. (2009). https://pifiada.blogspot.com.ar/2009/10/tejemaneje-entrevista-lauraalcoba.html Fecha de consulta: 21/09/2015.

Adorno, Theodor. Prismas. Barcelona: Ariel, 1962.

Agamben, Giorgio. Infancia e historia. Ciudad Autónoma de Buenos Aires: Adriana Hidalgo editora, 2015. . Lo que queda de Auschwitz. El archivo y el testigo. Valencia: Pre-Textos, 2010.

Ainsa, Fernando. "Nueva novela histórica y relativización del saber historiográfico". Casa de las Américas: Año XXXVI/número 202, (1996): 9-18.

Amícola, José. "Autoficción, una polémica literaria vista desde los márgenes (Borges, Gombrowicz, Copi, Aira)". Olivar. Año 9/volumen 1 (2008): 1197. http://www.fuentesmemoria.fahce.unlp.edu.ar/art_revistas/pr.3713/p r.3713.pdf Fecha de consulta: 21/11/2015.

Arendt, Hannah. Los orígenes del totalitarismo. Buenos Aires: Aguilar, Altea, Taurus, Alfaguara, 2010.

Arfuch, Leonor. Memoria y autobiografía. Exploraciones en los límites. Buenos Aires: Fondo de Cultura Económica, 2013.

Ariès, Philippe. Ensayos de la memoria. 1943-1983. Ciudad Autónoma de Buenos Aires: Waldhuter, 2016.

Bajtin, Mijail. Problemas de la poética de Dostoievski. México: Fondo de Cultura Económica, 1986.

Barthes, Roland. Lo neutro. México: Siglo XXI, 2004.

Benjamin, Walter. "El narrador". Para una crítica de la violencia y otros ensayos. Iluminaciones IV. Madrid: Taurus, 1991. 111-134.

Bettelheim, Bruno. Sobrevivir. El holocausto una generación después. Barcelona: Editorial Crítica, 1981. Traducción de Jordi Beltrán.

Blanchot, Maurice. La escritura del desastre. Caracas: Monte Ávila Editores, 1990. Traducción de Pierre de Place.

. El paso (no) más allá. Barcelona: Paidós, 1994.

Boccanera, Jorge. Tierra que anda. Los escritores en el exilio. Rosario: Ameghino, 1999. 
Bordelois, Ivonne. La palabra amenazada. Buenos Aires: Libros del zorzal, 2005.

Bruner, Jerome. La fábrica de historias. Derecho, literatura, vida. Buenos Aires: Fondo de Cultura Económica, 2013.

Calveiro, Pilar. Poder y desaparición. Los campos de concentración en Argentina. Buenos Aires: Colihue, 2006.

Candau, Joël. Antropología de la memoria. Buenos Aires: Nueva Visión, 2002.

Coira, María: "Modos recientes de la novela histórica" y "La operación de escritura: Poner la cosa ante los ojos: la representación en tanto problema". La serpiente y el nopal. Historia y ficción en la novelística mexicana de los 80. Buenos Aires: El otro el mismo, 2009. 23-45 y 46-68.

Crenzel, Emilio (coordinador). Los desaparecidos en la Argentina. Memorias, representaciones e ideas (1983-2008). Buenos Aires: Biblos, 2010.

Dalmaroni, Miguel. La palabra justa: Literatura, crítica y memoria en la Argentina, 1960-2002. Mar del Plata: Melusina, 2004.

Daona, Victoria. "'Había una vez una casa de los conejos'. Una lectura sobre la novela de Laura Alcoba”. Aletheia. Volumen 3/número 6 (2013): 1-17. http://www.aletheia.fahce.unlp.edu.ar/numeros/numero-6/pdfs/Daonaok.pdf. Fecha de consulta: 10/08/2017.

Derrida, Jaques. El monolingüismo del otro. Buenos Aires: Manantial, 2009. Traducción de Horacio Pons.

Didi-Huberman, Georges. Imágenes pese a todo. Memoria visual del Holocausto. Barcelona: Paidós, 2004. Traducción de Mariana Miracle. . Remontajes del tiempo padecido. El ojo de la historia. Volumen 2. Buenos Aires: Biblos-Universidad del cine, 2015. Traducción de Marina Califano.

Drucaroff, Elsa. Los prisioneros de la torre. Política, relatos y jóvenes en la postdictadura. Buenos Aires: Emecé, 2011.

Eco, Umberto. "El lector modelo". Lector in fabula, la cooperación interpretativa en el texto narrativo. Barcelona: Lumen, 1993. 73-95. Traducción de Ricardo Pochtar. . Decir casi lo mismo. Experiencias de traducción. Buenos Aires: Sudamericana, 2013. Traducción de Helena Lozano Miralles.

Feierstein, Daniel. Memorias y representaciones. Sobre la elaboración del genocidio. Buenos Aires: Fondo de Cultura Económica, 2012.

Fibla, Nuria Girona. "Escribir la historia y escribir las historias. La novela argentina de los 80". Casa de las Américas. (1996): 19-29.

Fisher, Ernst. "El problema de lo real en el arte moderno”. ¿Realismo: Mito, doctrina o tendencia histórica? Buenos Aires: Quadrata, 2004. 63-89.

Fleisner, Paula. "La posibilidad del poema o 'los poetas no olvidan'”. Jean-Luc Nancy y otros: Jean-Luc Nancy: arte, filosofía, política. Buenos Aires: Prometeo, 2012. 63-73.

Flier, Patricia. "La literatura del exilio y los trabajos de las memorias: la vuelta a 'el fuera de lugar'”. Patricia Flier, compiladora: Dilemas, apuestas y reflexiones teórico-metodológicas para los abordajes en Historia Reciente. La Plata: EDULP, 2014. 225-245. 
Forné, Anna. "La memoria insatisfecha en La casa de los conejos de Laura Alcoba". El hilo de la fábula. Número 10 (2010): 65-74.

Foucault, Michel. Las palabras y las cosas. Barcelona: Planeta-Agostini, 1985.

Halbwachs, Maurice. La memoria colectiva. Buenos Aires: Miño y Dávila, 2011. Traducción de Federico Balcarce.

Heidegger, Martin. Introducción a la metafísica. Barcelona: Gedisa, 1993.

Huffschmid, Anne. "Introducción. Topografías en conflicto". Anne Huffschmid y

Valeria Durán, coordinadoras. Topografías conflictivas. Memorias, espacios y ciudades en disputa. Buenos Aires: Nueva Trilce, 2012. 13-19.

Huyssen, Andreas. En busca del futuro perdido. Cultura y memoria en tiempos de globalización. Buenos Aires: Fondo de Cultura Económica, 2001.

Iggers, George. La ciencia histórica en el siglo XX. Barcelona: Idea universitaria, 1998.

Insúa, Gabriela (compiladora). Lo indecible. Clínica con lo traumático. Buenos Aires: Letra viva, 2013.

Jankélévitch, Vladimir (2006) [1994]. Pensar la muerte. Buenos Aires: Fondo de Cultura Económica. Traducción de Horacio Zabaljáuregui.

Jelin, Elizabeth. Los trabajos de la memoria. Lima: Instituto de Estudios Peruanos, 2012.

Klein, Irene. La ficción de la memoria: la narración de historias de vida. Buenos Aires: Prometeo Libros, 2008.

Kohan, Martín. El país de la guerra. Buenos Aires: Eterna cadencia, 2014.

LaCapra, Dominick . Escribir la historia, escribir el trauma. Buenos Aires: Nueva Visión, 2005.

. Historia en tránsito. Experiencia, identidad, teoría crítica. Buenos Aires: Fondo de Cultura Económica, 2006.

. Representar el Holocausto. Historia, teoría, trauma. Buenos Aires:

Prometeo, 2008.

Lacoue-Labarthe, Philippe y Jean-Luc Nancy. El pánico político. Adrogué:

Ediciones La Cebra y Editorial Palinodia, 2014. Traducción de Cristóbal Durán y Nicolás Gómez.

La Haije, Marileen. "Recomponer la historia familiar. Memoria, narración y (auto)biografía en La casa de los conejos de Laura Alcoba y El espíritu de mis padres sigue subiendo en la lluvia de Patricio Pron". Estudios de Teoría Literaria. Volumen 4/número 7 (2015): 1-11.

http://fh.mdp.edu.ar/revistas/index.php/etl/article/view/977/1147 Fecha de consulta: 10/08/2017.

Lejeune, Philippe. "El pacto autobiográfico". AA.VV. La autobiografía y sus problemas teóricos. Estudios e investigación documental. Anthropos, Suplementos, 29, 1991. 47-61.

Lespada, Gustavo. "La palabra golpeada”. Puentes. Año VII/número 21 (2007): 64-73.

Levi, Primo. Si esto es un hombre. Barcelona: Océano-El Aleph Editores, 2011. . Los hundidos y los salvados. Barcelona: Océano-El Aleph Editores, 2011. 
CATEDRAL TOMADA: Revista literaria latinoamericana / Journal of Latin American Literary Criticism Estefanía Luján Di Meglio

Lorenzano, Sandra. Escrituras de sobrevivencia. Narrativa argentina y dictadura. México D.F.: Universidad Autónoma Metropolitana, 2001.

Lozada, Martín. Sobre el genocidio. El crimen fundamental. Buenos Aires: Capital Intelectual, 2008.

Merbilhaá, Margarita. "Reseña crítica a La casa de los conejos". Boletín del Núcleo de Memoria. Número 14 (2013). http://www.comunikas.com.ar/nucleo/news_2.htm\#com3 Fecha de consulta: 30/02/2014.

Moyano, Daniel. Lenguaje y exilio. Alicante: Biblioteca Virtual Miguel de Cervantes, 2011. http://www.cervantes virtual.com/nd/ark:/59851/bmccn7p7 Fecha de consulta: 10/08/2017.

Nora, Pierre. La aventura de Les lieux de mémoire. Montevideo: Trilce, 2008.

Paz, Octavio. El mono gramático. Barcelona: Seix Barral, 2001.

Peller, Mariela. "La mirada de la niña. Sobre La casa de los conejos de Laura Alcoba". Question. Volumen 1/número 22 (2009). http://perio.unlp.edu.ar/ojs/index.php/question/article/view/796/698: 1-3.

Pollak, Michael. Memoria, olvido, silencio. La producción social de identidades frente a situaciones límite. Ediciones Al margen: La Plata, 2006.

Rancière, Jacques. Política de la literatura. Buenos Aires: Libros del zorzal, 2011.

Richard, Nelly. Fracturas de la memoria. Arte y pensamiento crítico. Buenos Aires: Siglo veintiuno, 2013.

Ricoeur, Paul. La memoria, la historia, el olvido. Buenos Aires: Fondo de Cultura Económica, 2008.

Robin, Régine. La memoria saturada. Buenos Aires: Waldhuter, 2012.

Rousseaux, Fabiana. "Memoria y verdad. Los juicios como rito restitutivo". Eduardo Luis Duhalde y otros. Acompañamiento a testigos en los juicios contra el terrorismo de Estado. Primeras experiencias. Buenos Aires: Ministerio de Justicia, Seguridad y Derechos Humanos de la Nación. Secretaría de Derechos Humanos, 2009.

Saban, Karen. "Inflexiones literarias en la materia del tiempo. Dos novelas argentinas sobre escritura y memoria". Orbis Tertius. Volumen XVI/número 17 (2011): 1-9. http://www.orbistertius.unlp.edu.ar/article/view/OTv16n17a04/4921 Fecha de consulta: 10/08/2017.

Sarlo, Beatriz. Tiempo pasado. Cultura de la memoria y giro subjetivo. Una discusión. Buenos Aires: Siglo veintiuno editores, 2005.

Steiner, George. Lenguaje y silencio. Ensayos sobre la literatura, el lenguaje y lo inhumano. Barcelona: Gedisa, 2000. . Extraterritorial. Buenos Aires: Adriana Hidalgo, 2009. Traducción de Edgardo Russo.

Todorov, Tzvetan. Los abusos de la memoria. Barcelona: Paidós, 2008.

Traducción de Miguel Salazar.

Traverso, Enzo. El pasado, instrucciones de uso. Buenos Aires: Prometeo, 2011. 
Vinyes, Ricard (editor). El Estado y la memoria. Buenos Aires: Del nuevo extremo-RBA, 2009.

Waldman Mitnick, Gilda. "Reseña de La casa de los conejos de Laura Alcoba". Revista Mexicana de Ciencias Politicas y Sociales. Volumen LII/número 210 (2010): 157-159. http://www.redalyc.org/articulo.oa?id=42118500008 Fecha de consulta: 10/08/2017.

White, Hayden. Ficción histórica, historia ficcional y realidad histórica. Buenos Aires: Prometeo Libros, 2010.

Williams, Raymond. Marxismo y literatura. Barcelona: Península, 1997. Traducción de Pablo di Masso.

Yerushalmi, Yosef y otros. Usos del olvido. Buenos Aires: Nueva Visión, 1989.

Žižek, Slavoj. Sobre la violencia. Seis reflexiones marginales. Buenos Aires: Paidós, 2013. Traducción de Antonio José Antón Fernández.

Zubieta, Ana María (compiladora). La memoria. Literatura, arte y política. Bahía Blanca: Universidad Nacional del Sur, 2008. 